\title{
A New Technique for Clipping Diaphragm Defects in Transsphenoidal Surgery
}

\author{
Transfenoidal Cerrabide Diyafram Defektlerinin Klipslenmesi İcin Yeni \\ Bir Teknik
}

\author{
Zhou PEIZHI ${ }^{1}$, Tang JIANJIAN ${ }^{2}$, Zhang JI ${ }^{1}$, Li YOUPING ${ }^{1}$, Jiang SHU ${ }^{1}$ \\ ${ }^{1}$ West China Hospital, Department of Neurosurgery, Chengdu, China \\ ${ }^{2}$ Affiliated Hospital to Hainan Medical College, Department of Neurosurgery, Haikou, China
}

Correspondence address: Jiang SHU / E-mail: jiangshu508@yahoo.com.cn

\begin{abstract}
AIM: To deal with postoperative CSF rhinorrhea, we developed a new technique using titanium/aneurysm clips to envelope the diaphragm defect to avoid postoperative CSF rhinorrhea.

MATERIAL and METHODS: From January 2007 through December 2010, we used a new technique of clipping diaphragm defects to prevent CSF rhinorrhea in 57 of 510 patients (group 1) who underwent transsphenoidal surgery. The incidence of postoperative CSF rhinorrhea was compared with that of 245 patients who underwent transsphenoidal surgery before the usage of this clipping technique between January 2004 and December 2006 (group 2).

RESULTS: Postoperative CSF rhinorrhea developed in 8 (1.57\%) patients of the 510 patients in group 1 while the new technique was used, while 17 (6.94\%) patients of the 245 patients in group 2 developed CSF rhinorrhea before the usage of this technique $(X 2=14.907, P<.001)$. No device-related complication such as optical chiasm herniation after clipping the diaphragm defect was observed.

CONCLUSION: Clipping the diaphragm defect with the titanium/aneurysm clips is effective and practicable to prevent postoperative CSF rhinorrhea, it can also avoid unnecessary autologous tissue grafting and postoperative lumbar drainage.
\end{abstract}

KEYWORDS: Diaphragm, Clip, Transsphenoidal surgery, Cerebrospinal fluid rhinorrhea

ÖZ

AMAÇ: Postoperatif BOS rinoresinin oluşmasını önlemek amacıyla diyafram defektini sarmak üzere titanyum/anevrizma klipsleri kullanan yeni bir teknik gelıştirilmiştir.

YÖNTEM ve GEREÇLER: Ocak 2007 ile Aralık 2010 arasında transfenoidal cerrahi yapılan 510 hastanın 57'sinde (grup 1) BOS rinorhesini önlemek için diyafram defektlerini klipsleme şeklinde geliştirdiğimiz yeni bir tekniği kullanılmıştır. Postoperatif BOS rinore insidansı Ocak 2004 ile Aralık 2006 arasında (grup 2) bu klipsleme tekniği kullanılmadan önce transfenoidal cerrahi yapılan 245 hastayla karşılaştırılmıştır.

BULGULAR: Postoperatif BOS rinoresi grup 1'de bu yeni tekniğin kullanıldığı 510 hasta içinden $8(\% 1,57)$ hastada gelişirken bu teknik kullanılmadan önce grup 2'deki 245 hastanın 17'sinde $(\% 6,94)$ BOS rinoresi gelişmiştir ( $\chi 2=14,907, P<0,001)$. Diyafram defekti klipslendikten sonra optik kiazma herniasyonu gibi cihazla ilişkili bir komplikasyon gözlenmemiştir.

SONUÇ: Diyafram defektinin titanyum/anevrizma klipsiyle klipslenmesi postoperatif BOS rinoresini önlemek açısından etkin ve pratiktir ve gereksiz otolog doku greftleme ve postoperatif lumber drenajı önleyebilir.

ANAHTAR SÖZCÜKLER: Diyafram, Klip, Transfenoidal cerrahi, Serebrospinal sıvı rinoresi

\section{INTRODUCTION}

Postoperative cerebrospinal fluid (CSF) rhinorrhea is one of the most common complications in transsphenoidal surgery (TSS). Many efforts have been made to facilitate sellar reconstruction in order to prevent CSF rhinorrhea from occurring, such as autologous tissue grafting using fat, muscle, fascia lata, and synthetic materials like hemostatic agents, fibrin glue and dural patch. Despite these efforts, postoperative CSF rhinorrhea remains a clinical challenge, although lumbar drainage was attempted to reduce CSF leakage (12). Watertight reconstruction of the diaphragm and dural defects is fundamental in preventing complications related to postoperative CSF leakage. Although some special techniques and instruments for direct dura mater suturing are described, they have not been widely accepted due to their complexity. In recent years, we developed a new technique of using titanium/aneurysm clips to envelope diaphragm defects in order to avoid postoperative CSF rhinorrhea and achieved successful outcomes in TSS.

\section{PATIENTS and METHODS}

This was a retrospective review of 755 patients with pituitary adenoma who underwent standard TSS in our department, 
in whom the sellar floor was reconstructed by sponge, dural patch, nasal septum bone, and BioGlue ${ }^{\circledR}$.

Of 510 patients (group 1) that received microscopic TSS from January 2007 to December 2010, diaphragm defects were clipped with titanium/aneurysm clips in 57 cases. The new technique was indicated during the operation for patients whose dilated diaphragms with small and moderate diaphragm defects had bagged into the intrasellar region. Another group of 245 patients (group 2) who received TSS without using the new technique from January 2004 to December 2006 was used as the control. In patients without any detectable diaphragm defect, or whose extended diaphragm did not bag into the intrasellar region, the sella was reconstructed as usual. For the patients in group 2 with intraoperative CSF leak and the patients in group 1 with large diaphragm/dura defects, the sellar floor was reconstructed with routine methods plus autologous tissue grafting as fat, muscle and fascia lata. Most patients (710) in both groups were evaluated clinically, and magnetic resonance imaging (MRI) was performed 3-48 months after surgery. There was no significant difference in age, sex and tumor volume between the two groups as shown in Table I.

The details of this new technique, instruments and the postoperative states are illustrated in Figures 1A-D, 2A-D. In cases with the perforated diaphragm bagged into the intrasellar region after tumor resection, the diaphragm was pulled up by suction or with tumor grasping forceps as the CSF leak and location was confirmed, and titanium/aneurysm clips were used to envelope the perforation and crimple the bagged diaphragm. As a result, CSF weeping was stopped. The sellar floor was reconstructed moderately to hold the clip in a proper position with sponge, dural patch, nasal septum bone, or BioGlue ${ }^{\circledR}$. Nasal septal bone was used for sellar floor reconstruction. This technique could not be applied as before in case the diaphragm defect was too large to be anastomosed. In cases where no diaphragm defect was detected, or where CSF leakage was very small, the sella was reconstructed as usual.

Special postoperative attention should be paid to any symptom and sign of CSF rhinorrhea in all patients. If postoperative CSF leak occurred, lumbar drainage was initiated immediately to manage the postoperative CSF rhinorrhea.

\section{Data analysis}

Rates of intraoperative and postoperative CSF leaks were compared between the two groups (group 1 and group 2) using chi-square test with the SPSS 17.0 software.

\section{RESULTS}

The postoperative CSF rhinorrhea incidence was $1.57 \%$ in group 1, and $6.94 \%$ in group 2 . There was no significant difference in intraoperative CSF fistula incidence between group 1 and 2 (200/310 vs. 87/158, X2=0.964, $P=.326)$. The occurrence of postoperative CSF rhinorrhea was significantly lower in group 1 than that in group 2 (8/502 vs. 17/228, $X 2=14.907, P<.001$ ), shown in Table II. In the patients which the new technique were used, no visible deterioration occurred during a follow-up period of 3-48 months. There was no significant difference in other complications between the two groups, and the diaphragm was at the normal site and the pituitary was protected properly on the CT and MRI scan, as shown in Figure 2D. All 57 patients of group 1 were discharged within a week after operation.

\section{DISCUSSION}

All 755 patients with pituitary adenoma were treated with standard TSS. All moderate diaphragm defects in 57 patients of group 1 were repaired successfully with the titanium/

Table I: Patient Characteristics

\begin{tabular}{l|c|c} 
& Group 1 & Group 2 \\
\hline Total cases $(n=755)$ & 510 & 245 \\
Age & $51.35 \pm 13.17$ & $49.25 \pm 16.34$ \\
Sex (male/female) & $221 / 289$ & $117 / 128$ \\
Pituitary adenoma & & 32 \\
$\quad$ microadenoma & 51 & 213
\end{tabular}

Table II: Intraoperative CSF Leak, Clipping Repair and Postoperative CSF Leak

\begin{tabular}{|c|c|c|c|c|}
\hline & $\begin{array}{c}\text { No. of intraoperative } \\
\text { CSF leaks }\end{array}$ & $\begin{array}{c}\text { No. of } \\
\text { new procedures }\end{array}$ & $\begin{array}{l}\text { No. of postoperative } \\
\text { CSF leaks }\end{array}$ & $\begin{array}{c}\text { No. of } \\
\text { patients included }\end{array}$ \\
\hline Group 1 & & & & 510 \\
\hline Microadenoma & 4 & 0 & 1 & 51 \\
\hline Macroadenoma & 196 & 57 & 3 & 459 \\
\hline Group 2 & & & & 245 \\
\hline Microadenoma & 2 & 0 & 0 & 32 \\
\hline Macroadenoma & 85 & 0 & 17 & 213 \\
\hline
\end{tabular}




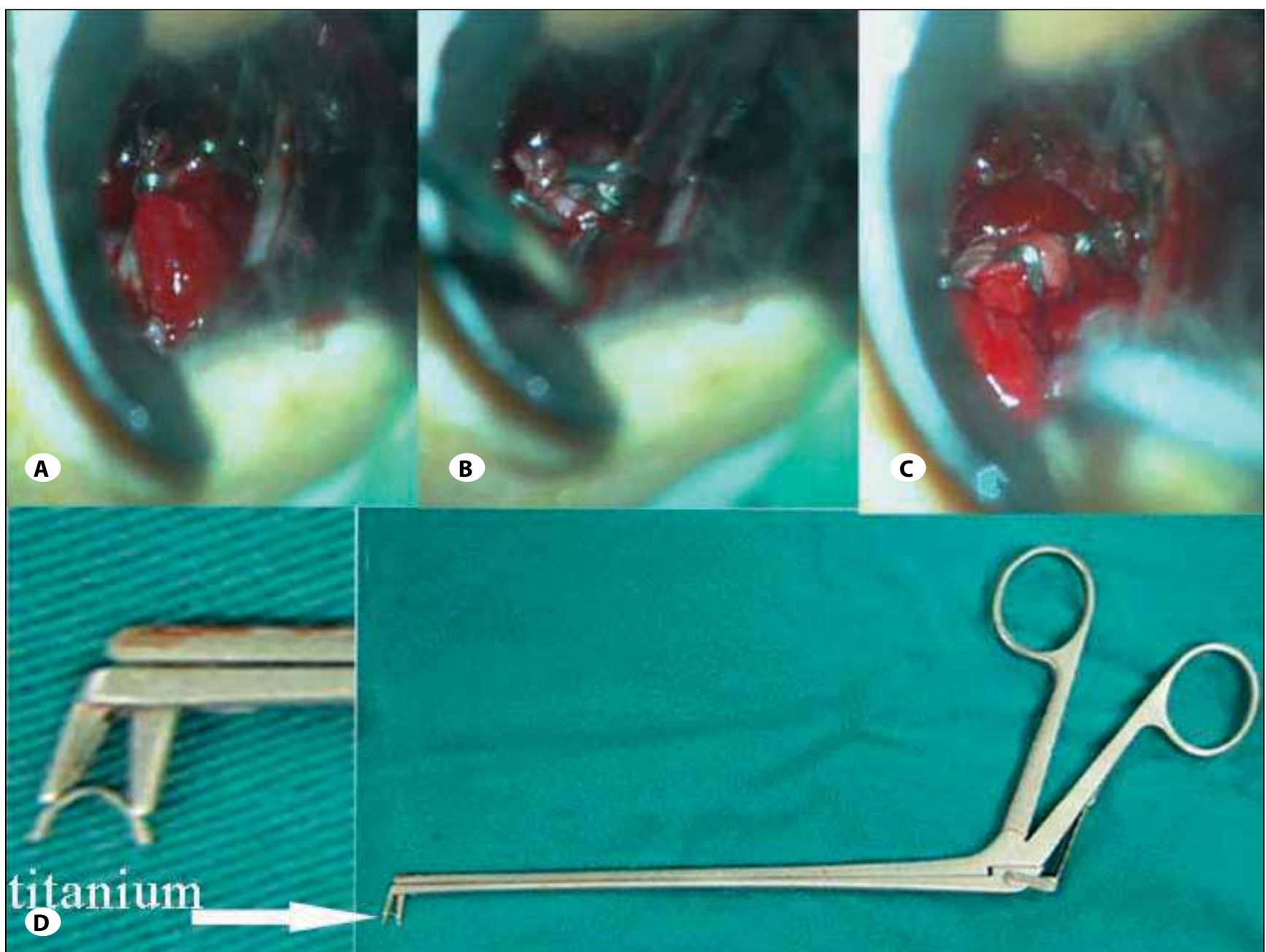

Figure 1: For the No.1 patient, after the tumor was resected, the diaphragm bagged into the intrasellar region (A), then we sucked the dilated diaphragm with the suction and clipped the defect with titanium clips (B) with the help of the titanium forceps (D). The diaphragm defect was clipped and CSF weeping was stopped (C).

aneurysm clips, and no postoperative CSF rhinorrhea occurred in these patients, indicating that this new technique is easy to follow and practicable, and may help avoid CSF rhinorrhea and potential lumbar drainage.

Postoperative CSF rhinorrhea is related to many factors, including the history of initial TSS and radiotherapy. Clipping the diaphragm defect is very important and effective in dealing with intraoperative CSF leak, because the diaphragm is upstream of the leakage. Although many neurosurgeons have focused on the prevention of CSF leakage, few have noticed the effect of the diaphragm in this process. Kelly et al first used a piece of collagen sponge fashioned to cover the exposed diaphragm defect to avoid CSF rhinorrhea (7). Several closure methods are available for the prevention of CSF leakage, including suturing the sellar dura mater instead of the conventional packing technique $(1,9)$. Those closure methods are effective but the diaphragm clipping technique could achieve the same efficiency easily instead of using the complicated dura mater suture methods in some cases with small diaphragm defects.
After tumor resection, the expanded diaphragm bagged into the sella, causing CSF leakage through the defect. After the bagged diaphragm is sucked and held upwards, it is easy to clip it with a titanium/aneurysm clip and stop CSF weeping directly. During the operation, the pituitary stalk is usually translocated laterally because of tumor compression and it could be protected during the clipping procedure. However, this procedure should be performed carefully in order to protect the pituitary stalk if the defect is not in the middle of the visual field. This technique should not be used if it is difficult to discriminate the compressed pituitary stalk and diaphragm.

More importantly, this technique can effectively avoid postoperative CSF rhinorrhea. In our series of 57 patients in whom the titanium/aneurysm clips were used to envelope the diaphragm, no postoperative CSF rhinorrhea occurred. The total incidence of postoperative CSF rhinorrhea was brought down to $1.57 \%$ after this new technique was used. This result is comparable to Dusick (3), Kitano et al introduced a subdural double-layer patch graft technique in preventing 


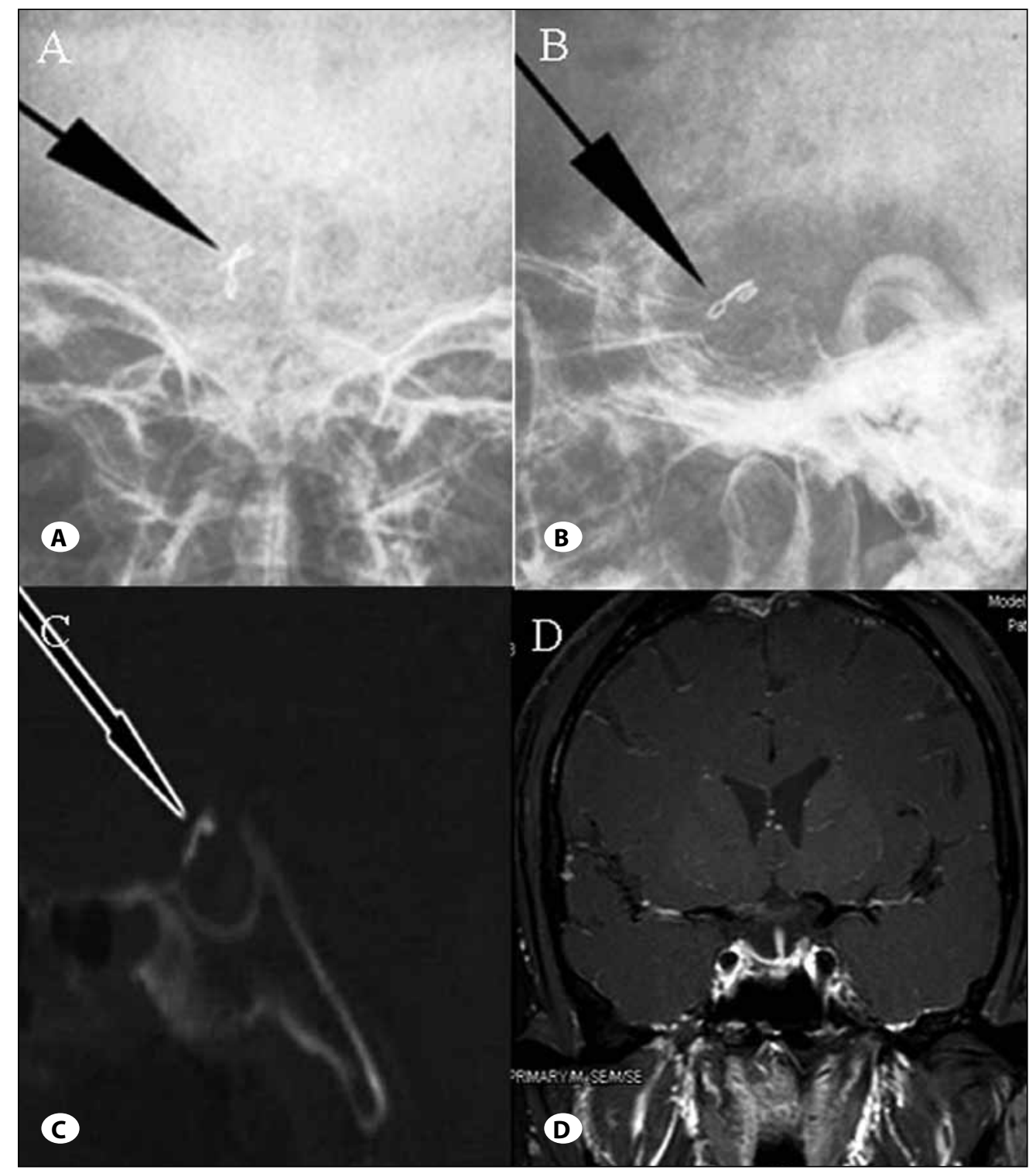

Figure 2: Anteroposterior (A) and lateral (B) views of skull X-rays for the No.2 patient, show a titanium and an aneurysm clip that did not move 12 months after the operation. The clips were also at the normal diaphragm site, the pituitary stalk and the pituitary was protected properly on the $\mathrm{CT}$ and MRI $\operatorname{scan}(\mathbf{C}, \mathbf{D})$.
CSF rhinorrhea after transsphenoidal surgery associated with a widely opened dura (9). Kaptain et al reconstructed the skull base with a bioabsorbable implant (6). The continuous lumbar CSF drainage system may also play an important role in the treatment of postoperative CSF rhinorrhea. Several other methods and materials have been used for the repair of the sellar floor $(1,3,4,5,6,9,11,12,13)$, and the use of autologous materials seems more effective $(1,5,7)$ than other materials $(2,3,9,13)$. Although some are effective in repairing severe sellar floor defects with large CSF leakage, the procedures are not practical enough to stop CSF leak immediately. In some cases with intra-suprasellar extension whose adenoma cannot be resected totally and whose diaphragm could not bag into the sella, we cannot clip the diaphragm defect with the titanium/aneurysm clip. In such cases, some more complicated repair techniques should be used to prevent postoperative CSF rhinorrhea from occurring, though they need special instruments and BioGlue ${ }^{\circledast}$.
We noticed that CSF leaks into the sella through the diaphragm defect during the process of surgery, and the bagged diaphragm was thin and dilated. When it was usually difficult to close the defect watertight, we decided to pack the sella with a graft and some material must be used to fill the cavity. The overpacked intrasellar region may be a new mass which may cause visual deterioration. Even in cases where no defect and CSF leakage are detected, clipping the bagged diaphragm is also helpful to fashion the diaphragm to avoid overpacking and dilation of the diaphragm. This technique may also help avoid secondary empty sella after the TSS (10).

Although the new technique described herein has proven effective in clipping diaphragm defects as demonstrated in our series, the titanium/aneurysm clip is not specifically designed for TSS, and therefore the holder should be revised to adapt to transsphenoidal approach for easy clipping in this deep and narrow space. 


\section{REFERENCES}

1. Ahn JY, Kim SH: A new technique for dural suturing with fascia graft for cerebrospinal fluid leakage in transsphenoidal surgery. Neurosurgery 65:65-71, 2009

2. Cho JM, Ahn JY, Chang JH, Kim SH: Prevention of cerebrospinal fluid rhinorrhea after transsphenoidal surgery by collagen fleece coated with fibrin sealant without autologous tissue graft or postoperative lumbar drainage. Neurosurgery 68:130-136, 2011

3. Dusick JR, Mattozo CA, Esposito F, Kelly DF: BioGlue for prevention of postoperative cerebrospinal fluid leaks in transsphenoidal surgery: A case series. Surg Neurol 66: 371-376, 2006

4. El-Banhawy OA, Halaka AN, El-Dien AE, Ayad H: Sellar floor reconstruction with nasal turbinate tissue after endoscopic endonasal transsphenoidal surgery for pituitary adenomas. Minim Invasive Neurosurg 46:289-292, 2003

5. Esposito F, Dusick JR, Fatemi N, Kelly DF: Graded repair of cranial base defects and cerebrospinal fluid leaks in transsphenoidal surgery. Neurosurgery 60:295-303, 2007

6. Kaptain GJ, Kanter AS, Hamilton DK, Laws ER: Management and implications of intraoperative cerebrospinal fluid leak in transnasoseptal transsphenoidal microsurgery. Neurosurgery 68:144-150, 2011
7. Kaptain GJ, Vincent DA, Laws ER Jr: Cranial base reconstruction after transsphenoidal surgery with bioabsorbable implants: Technical note. Neurosurgery 48:232-234, 2001

8. Kelly DF, Oskouian RJ, Fineman I: Collagen sponge repair of small cerebrospinal fluid leaks obviates tissue grafts and cerebrospinal fluid diversion after pituitary surgery. Neurosurgery 49:885-889, 2001

9. Kitano M, Taneda M: Subdural patch graft technique for watertight closure of large dural defects in extended transsphenoidal surgery. Neurosurgery 54:653-660, 2004

10. Naing S, Frohman LA: The empty sellar. Pediatr Endocrinol Rev 4:335-342, 2007

11. Nishioka H, Izawa $H$, Ikeda $Y$, Namatame H, Fukami S, Haraoka J: Dural suturing for repair of cerebrospinal fluid leak in transnasal transsphenoidal surgery. Acta Neurochir (Wien) 151:1427-1430, 2009

12. Sade B, Mohr G, Frenkiel S: Management of intra-operative cerebral luid leak in transnasal transsphnoidal pituitary microsurgery: Use of post-operative lumbar drain and sellar reconstruction without fat packing. Acta Neurochir (Wien) 148:13-18, 2006

13. Seda L, Camara RB, Cukiert A, Burattini JA, Mariani PP: Sellar floor reconstruction after transsphenoidal surgery using fibrin glue without grafting or implants:technical note. Surg Neurol 66:46-49, 2006 